for conservation globally

Threatened

通
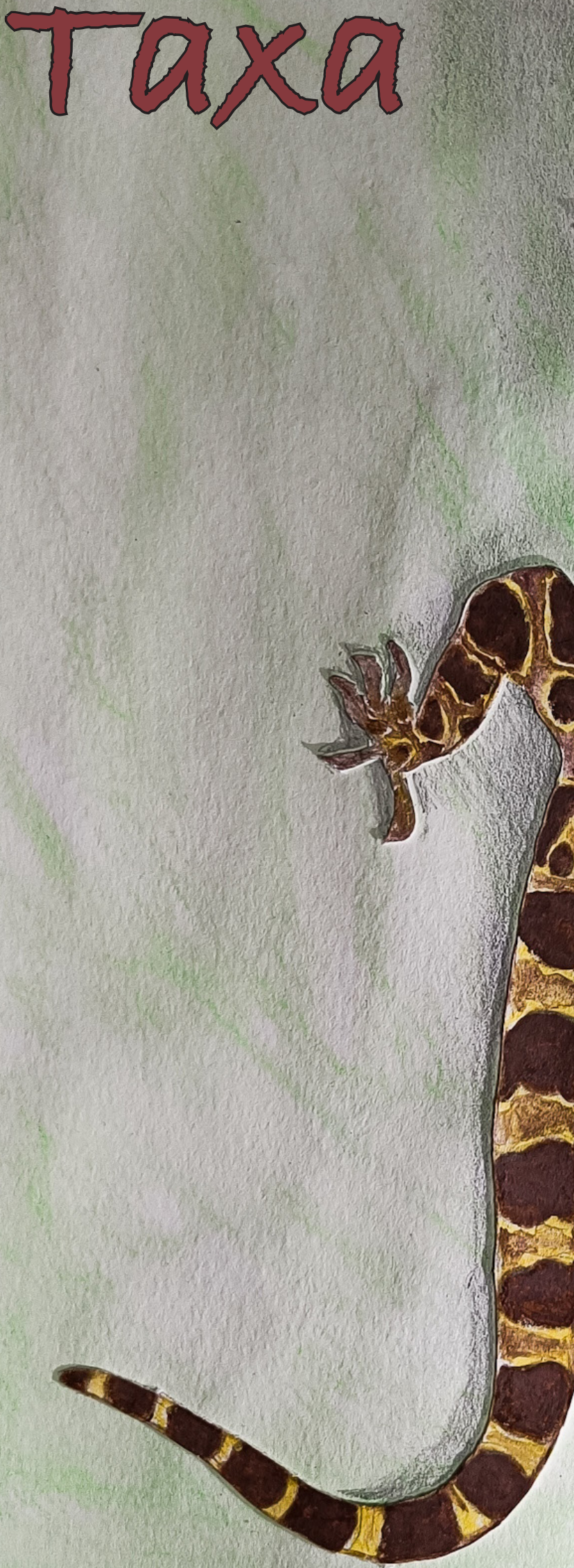

Open Access

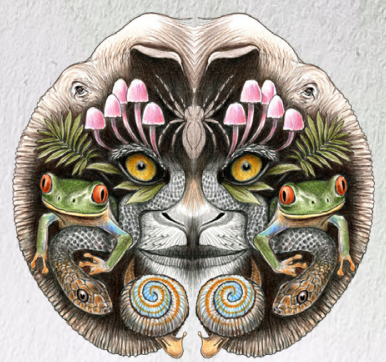

$10.1160 \mathrm{~g} / \mathrm{j}$ ott.2022.14.1.20311-20538 wWw.threatenedtaxa.org

26 January 2022 (Online \& Print) 14(1): 20311-20538 ISSN0974-7907 (Online) ISSN 0974-7893 (Print) 


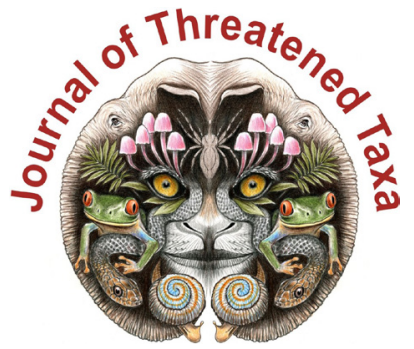

ISSN 0974-7907 (Online); ISSN $0974-7893$ (Print)

Publisher

Host

Wildlife Information Liaison Development Society

www.wild.zooreach.org

Zoo Outreach Organization www.zooreach.org

No. 12, Thiruvannamalai Nagar, Saravanampatti - Kalapatti Road, Saravanampatti, Coimbatore, Tamil Nadu 641035, India

Ph: +91 9385339863 | www.threatenedtaxa.org

Email: sanjay@threatenedtaxa.org

EDITORS

\section{Founder \& Chief Editor}

Dr. Sanjay Molur

Wildlife Information Liaison Development (WILD) Society \& Zoo Outreach Organization (ZOO),

12 Thiruvannamalai Nagar, Saravanampatti, Coimbatore, Tamil Nadu 641035, India

\section{Deputy Chief Editor}

Dr. Neelesh Dahanukar

Noida, Uttar Pradesh, India

\section{Managing Editor}

Mr. B. Ravichandran, WILD/ZOO, Coimbatore, India

\section{Associate Editors}

Dr. Mandar Paingankar, Government Science College Gadchiroli, Maharashtra 442605, India

Dr. Ulrike Streicher, Wildlife Veterinarian, Eugene, Oregon, USA

Ms. Priyanka Iyer, ZOO/WILD, Coimbatore, Tamil Nadu 641035, India

Dr. B.A. Daniel, ZOO/WILD, Coimbatore, Tamil Nadu 641035, India

\section{Editorial Board}

Dr. Russel Mittermeier

Executive Vice Chair, Conservation International, Arlington, Virginia 22202, USA

\section{Prof. Mewa Singh Ph.D., FASc, FNA, FNASc, FNAPsy}

Ramanna Fellow and Life-Long Distinguished Professor, Biopsychology Laboratory, and Institute of Excellence, University of Mysore, Mysuru, Karnataka 570006, India; Honorary Professor, Jawaharlal Nehru Centre for Advanced Scientific Research, Bangalore; and Adjunct Professor, National Institute of Advanced Studies, Bangalore

\section{Stephen D. Nash}

Scientific Illustrator, Conservation International, Dept. of Anatomical Sciences, Health Sciences Center, T-8, Room 045, Stony Brook University, Stony Brook, NY 11794-8081, USA

\section{Dr. Fred Pluthero}

Toronto, Canada

\section{Dr. Priya Davidar}

Sigur Nature Trust, Chadapatti, Mavinhalla PO, Nilgiris, Tamil Nadu 643223, India

\section{Dr. Martin Fisher}

Senior Associate Professor, Battcock Centre for Experimental Astrophysics, Cavendish

Laboratory, JJ Thomson Avenue, Cambridge CB3 OHE, UK

\section{Dr. John Fellowes}

Honorary Assistant Professor, The Kadoorie Institute, 8/F, T.T. Tsui Building, The University of Hong Kong, Pokfulam Road, Hong Kong

\section{Prof. Dr. Mirco Solé}

Universidade Estadual de Santa Cruz, Departamento de Ciências Biológicas, Vice-coordenado do Programa de Pós-Graduação em Zoologia, Rodovia Ilhéus/Itabuna, Km 16 (45662-000)

Salobrinho, Ilhéus - Bahia - Brasil

\section{Dr. Rajeev Raghavan}

Professor of Taxonomy, Kerala University of Fisheries \& Ocean Studies, Kochi, Kerala, India

\section{English Editors}

Mrs. Mira Bhojwani, Pune, India

Dr. Fred Pluthero, Toronto, Canad

Mr. P. Ilangovan, Chennai, India

Web Development

Mrs. Latha G. Ravikumar, ZOO/WILD, Coimbatore, India

\section{Typesetting}

Mr. Arul Jagadish, ZOO, Coimbatore, India

Mrs. Radhika, ZOO, Coimbatore, India

Mrs. Geetha, ZOO, Coimbatore India
Fundraising/Communications

Mrs. Payal B. Molur, Coimbatore, India

Subject Editors 2018-2020

Fungi

Dr. B. Shivaraju, Bengaluru, Karnataka, India

Dr. R.K. Verma, Tropical Forest Research Institute, Jabalpur, India

Dr. Vatsavaya S. Raju, Kakatiay University, Warangal, Andhra Pradesh, India

Dr. M. Krishnappa, Jnana Sahyadri, Kuvempu University, Shimoga, Karnataka, India

Dr. K.R. Sridhar, Mangalore University, Mangalagangotri, Mangalore, Karnataka, India

Dr. Gunjan Biswas, Vidyasagar University, Midnapore, West Bengal, India

\section{Plants}

Dr. G.P. Sinha, Botanical Survey of India, Allahabad, India

Dr. N.P. Balakrishnan, Ret. Joint Director, BSI, Coimbatore, India

Dr. Shonil Bhagwat, Open University and University of Oxford, UK

Prof. D.J. Bhat, Retd. Professor, Goa University, Goa, India

Dr. Ferdinando Boero, Università del Salento, Lecce, Italy

Dr. Dale R. Calder, Royal Ontaro Museum, Toronto, Ontario, Canada

Dr. Cleofas Cervancia, Univ. of Philippines Los Baños College Laguna, Philippines

Dr. F.B. Vincent Florens, University of Mauritius, Mauritius

Dr. Merlin Franco, Curtin University, Malaysia

Dr. V. Irudayaraj, St. Xavier's College, Palayamkottai, Tamil Nadu, India

Dr. B.S. Kholia, Botanical Survey of India, Gangtok, Sikkim, India

Dr. Pankaj Kumar, Kadoorie Farm and Botanic Garden Corporation, Hong Kong S.A.R., China

Dr. V. Sampath Kumar, Botanical Survey of India, Howrah, West Bengal, India

Dr. A.J. Solomon Raju, Andhra University, Visakhapatnam, India

Dr. Vijayasankar Raman, University of Mississippi, USA

Dr. B. Ravi Prasad Rao, Sri Krishnadevaraya University, Anantpur, India

Dr. K. Ravikumar, FRLHT, Bengaluru, Karnataka, India

Dr. Aparna Watve, Pune, Maharashtra, India

Dr. Qiang Liu, Xishuangbanna Tropical Botanical Garden, Yunnan, China

Dr. Noor Azhar Mohamed Shazili, Universiti Malaysia Terengganu, Kuala Terengganu, Malaysia

Dr. M.K. Vasudeva Rao, Shiv Ranjani Housing Society, Pune, Maharashtra, India

Prof. A.J. Solomon Raju, Andhra University, Visakhapatnam, India

Dr. Mandar Datar, Agharkar Research Institute, Pune, Maharashtra, India

Dr. M.K. Janarthanam, Goa University, Goa, India

Dr. K. Karthigeyan, Botanical Survey of India, India

Dr. Errol Vela, University of Montpellier, Montpellier, France

Dr. P. Lakshminarasimhan, Botanical Survey of India, Howrah, India

Dr. Larry R. Noblick, Montgomery Botanical Center, Miami, USA

Dr. K. Haridasan, Pallavur, Palakkad District, Kerala, India

Dr. Analinda Manila-Fajard, University of the Philippines Los Banos, Laguna, Philippines

Dr. P.A. Sinu, Central University of Kerala, Kasaragod, Kerala, India

Dr. Afroz Alam, Banasthali Vidyapith (accredited A grade by NAAC), Rajasthan, India

Dr. K.P. Rajesh, Zamorin's Guruvayurappan College, GA College PO, Kozhikode, Kerala, India

Dr. David E. Boufford, Harvard University Herbaria, Cambridge, MA 02138-2020, USA

Dr. Ritesh Kumar Choudhary, Agharkar Research Institute, Pune, Maharashtra, India

Dr. Navendu Page, Wildlife Institute of India, Chandrabani, Dehradun, Uttarakhand, India

\section{Invertebrates}

Dr. R.K. Avasthi, Rohtak University, Haryana, India

Dr. D.B. Bastawade, Maharashtra, India

Dr. Partha Pratim Bhattacharjee, Tripura University, Suryamaninagar, India

Dr. Kailash Chandra, Zoological Survey of India, Jabalpur, Madhya Pradesh, India

Dr. Ansie Dippenaar-Schoeman, University of Pretoria, Queenswood, South Africa

Dr. Rory Dow, National Museum of natural History Naturalis, The Netherlands

Dr. Brian Fisher, California Academy of Sciences, USA

Dr. Richard Gallon, llandudno, North Wales, LL30 1UP

Dr. Hemant V. Ghate, Modern College, Pune, India

Dr. M. Monwar Hossain, Jahangirnagar University, Dhaka, Bangladesh

Mr. Jatishwor Singh Irungbam, Biology Centre CAS, Branišovská, Czech Republic.

Dr. Ian J. Kitching, Natural History Museum, Cromwell Road, UK

Dr. George Mathew, Kerala Forest Research Institute, Peechi, India

For Focus, Scope, Aims, and Policies, visit https://threatenedtaxa.org/index.php/JoTT/aims_scope
For Article Submission Guidelines, visit https://threatenedtaxa.org/index.php/JoTT/about/submissions
For Policies against Scientific Misconduct, visit https://threatenedtaxa.org/index.php/JoTT/policies_various

continued on the back inside cover 
Journal of Threatened Taxa | www.threatenedtaxa.org | 26 January 2022 | 14(1):20494-20499

ISSN0974-7907 (Online) | ISSN0974-7893 (Print)

\title{
Trypanosoma evansi infection in a captive Indian Wolf Canis lupus pallipes - molecular diagnosis and therapy
}

\author{
Manojita Dash ${ }^{1}$ (D), Sarat Kumar Sahu ${ }^{2}$ (D), Santosh Kumar Gupta ${ }^{3}$ (D), Niranjana Sahoo ${ }^{4}$ (D) \\ \& Debarat Mohapatra ${ }^{5}$ iD
}

\author{
${ }_{1,3}$ Centre for Wildlife Health, College of Veterinary Science \& Animal Husbandry, Odisha University of Agriculture and Technology, \\ Bhubaneswar, Odisha 751003, India \\ 2,5 Nandankanan Zoological Park, Po-Barang, Khordha District, Odisha 754005, India. \\ ${ }^{4}$ Department of Preventive Veterinary Medicine and Epidemiology, College of Veterinary Science \& Animal Husbandry, \\ Odisha University of Agriculture \& Technology, Bhubaneswar, Odisha 751003, India \\ ${ }^{1}$ manojita.dash@gmail.com, ${ }^{2}$ sahu.sarat77@gmail.com (corresponding author), ${ }^{3}$ santoshkumargupta67@ymail.com, \\ ${ }^{4}$ niranjanasahoo@hotmail.com, ${ }^{5}$ debabrat73@gmail.com
}

\begin{abstract}
A five-year old, apparently healthy male Indian Wolf Canis lupus pallipes of Nandankanan Zoological Park, Odisha became ill with acute signs of anorexia, lethargy, staggering gait, and was non-responsive to external stimuli. Microscopic examination of Giemsa stained blood smear revealed presence of extracellular flagellates having morphological similarity to Trypanosoma spp. Haematological parameters showed anaemia ( $\mathrm{Hb} 6.0 \mathrm{~g} \%)$, mild leucopenia (total leukocyte count $\left.5 \times 10^{3} / \mathrm{mm}^{3}\right)$ and thrombocytopenia $\left(180 \times 10^{3} / \mu \mathrm{l}\right)$. Serum biochemistry revealed high aspartate aminotransferase (AST) (830 IU/L), blood urea nitrogen (BUN) (178.2 mg/dl), creatinine (4.44 $\mathrm{mg} / \mathrm{dl})$, and low glucose $(25.7 \mathrm{mg} / \mathrm{dl})$ levels. Polymerase chain reaction (PCR) analysis targeting internal transcribed spacer (ITS1) region followed by National Centre for Biotechnology Information blast confirmed Trypanosoma evansi infection in the captive Indian Wolf. The animal showed clinical recovery with the administration of single dose of quinapyramine sulphate and quinapyramine chloride @ $4.0 \mathrm{mg} /$ $\mathrm{kg} b$ wt subcutaneously. The wolf started taking meat from the very next day with improved activity. No trypanosomes could be detected in the stained blood smears as well as through PCR carried 25 days post treatment. The occurrence became an eye opener for the zoo and henceforth, all canids were included under chemoprophylaxis protocol against trypanosomosis.
\end{abstract}

Keywords: Anemia, Canids, captivity stress, Chemoprophylaxis, PCR, Quinapyramine salts.

Editor: Rajeshkumar G. Jani, Anand Agricultural University, Anand, India.

Date of publication: 26 January 2022 (online \& print)

Citation: Dash, M., S.K. Sahu, S.K. Gupta, N. Sahoo \& D. Mohapatra (2022). Trypanosoma evansi infection in a captive Indian Wolf Canis /upus pallipes - molecular diagnosis and therapy. Journal of Threatened Taxa 14(1): 20494-20499. https://doi.org/10.11609/jott.7578.14.1.20494-20499

Copyright: @ Dash et al. 2022. Creative Commons Attribution 4.0 International License. JoTT allows unrestricted use, reproduction, and distribution of this article in any medium by providing adequate credit to the author(s) and the source of publication.

Funding: This study is a part of normal healthcare activity of the zoo (Nandankanan Zoological Park) which is under the control of 'Forest and Environment Department, Government of Odisha'. No separate fund has been received from any agency for this study.

Competing interests: The authors declare no competing interests.

Author details: Manojita Dash, MSc Biotechnology-She is working as Senior Research Fellow at Centre for Wildlife Health (CWH), CVSc \& AH, OUAT, Bhubaneswar. She is actively involved in the processing of bio-samples collected from Nandankanan Zoological Park as well as various other zoos and sanctuaries of Odisha. She is well versed with handling of sophisticated instruments used in analysis of the bio-samples, data interpretation, statistical analysis. Sarat Kumar Sahu, MVSc, Veterinary Microbiology-He is working as Veterinary Assistant Surgeon at Nandankanan Zoological Park since more than 11 years. He is actively involved in treatment, preventive health care, conservation and scientific research related to captive and free ranging wild animals. Santosh Kumar Gupta-He has completed M.V.Sc. in Veterinary Clinical Medicine, Ethics and Jurisprudence from College of Veterinary Science, Guwahati, Assam and has been engaged as Research Associate at Centre for Wildlife Health, OUAT. He has keen interest in Wildlife and conservation science and has been carrying out scientific research work at Nandankanan Zoological Park. Niranjana Sahoo, MVSc, PhD-He is the Professor and Head, Department of Veterinary Epidemiology and Preventive Medicine, and Director, Teaching Veterinary Clinical Complex, CVSc \& AH, OUAT. He is also the Coordinator, Centre for Wildlife Health (CWH), OUAT. CWH is serving as the microbiological, molecular and forensic diagnostic hub for captive and free ranging wild animal diseases of the entire Odisha state. Debabrat Mohapatra-He has done MVSc in Veterinary Clinical Medicine. He is currently working as Medicine Specialist at Nandankanan Zoological Park since last six years. He has keen interest in treatment and preventive healthcare of captive wild animals of the zoo.

Author contributions: SKS, SKG and DM have executed the treatment, collected samples and documented the clinical findings. MD and NS have carried out molecular screening, interpreted the results and guided the treatment. All authors formulated and revised the manuscript, and approved the final version.

Acknowledgements: Authors are thankful to the Director, Nandankanan Zoological Park, Odisha for extending necessary facilities to carry out this in situ study and to publish this manuscript.

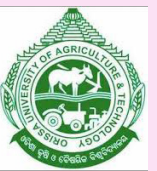




\section{INTRODUCTION}

Trypanosomosis, caused by an unicellular, eukaryotic haemoprotozoan of different Trypanosoma spp., is an important disease of domestic and wild animals (Aulakh et al. 2005; Gupta et al. 2009). A number of trypanosomes exist worldwide; however, Trypanosoma evansi is the only pathogenic species prevalent in India (Desquesnes et al. 2001; Kumar et al. 2021). Sengupta (1974), Ziauddin et al. (1992), and Shukla (2002) reported trypanosomosis in Indian Wolves in Indian zoos at Kolkata, Mysore, and Lucknow, respectively. This extra-cellular haemoparasite is transmitted by biting flies of genera Tabanus, Stomoxys, and Haematobia (Parashar et al. 2006, 2018). The disease is characterized by anaemia, anorexia, intermittent fever, generalised weakness, conjunctivitis, corneal opacity, oedema of head and throat, difficulty in swallowing, hoarse voice, and staggering gait (Chaudhuri et al. 2009). The disease can be diagnosed by direct demonstration of trypomastigote forms of the parasite in the stained blood smears, but the polymerase chain reaction (PCR) has an increased diagnostic potential with high sensitivity and specificity to detect parasite DNA (Eloy \& Lucheis 2009). Trypanosomosis has been successfully treated with a single dose of diminazine aceturate @ 3.5 $\mathrm{mg} / \mathrm{kg}$ body weight intramuscular (Rani \& Suresh 2007) or sulphate and chloride salts of quinapyramine @ 4.0 $\mathrm{mg} / \mathrm{kg}$ bw subcutaneous (Singh et al. 1993).The present case study documents molecular diagnosis through PCR and successful therapy of Trypanosoma evansi infection in a captive Indian Wolf at Nandankanan Zoological Park (NKZP), India.

\section{CASE HISTORY AND OBSERVATION}

The NKZP received a pair of wolves during September 2018 from Sri Chamarajendra Zoological Gardens, Mysuru under an animal exchange program. Both were housed in an open air enclosure of 28 sq meters attached to a feeding cell of $15 \mathrm{sq}$ meters. Regular prophylactic measures included annual vaccination against rabies, parvo, distemper, parainfluenza, adenovirus type I and II, hepatitis and Leptospira spp., fecal sample examination followed by deworming with albendazole/ fenbendazole at three month intervals and ground spray of enclosure with ectoparasiticides deltamethrine/cypermethrine in alternate months. The female partner died on 07 March 2019 due to cardiac dysfunction leaving the male wolf alone.
On 24 September 2019, the 5-year old apparently healthy male partner (approximate body weight 20.0 $\mathrm{kg}$ ) was noticed anorectic, debilitated, non-responsive to external stimuli, reduced activity levels with staggering gait. Close examination inside a squeeze cage revealed shallow breathing and pale conjunctiva. Body temperature was $103.2^{\circ} \mathrm{F}$. Peripheral blood samples were collected on the same day from the left saphenous vein in ethylene diamine tetraacetic acid @ $1.5 \mathrm{mg} / \mathrm{ml}$ (EDTA) and clot activator vials for haemato-biochemical and parasitological examination. Faecal samples were collected for detection of gastrointestinal infection.

\section{DIAGNOSIS AND TREATMENT}

Coprological examination did not reveal the presence of any endoparasite ova or cyst. Blood smear stained with Giemsa stain and examined under oil immersion showed the presence of extracellular flagellated Trypanosomes (Image 1). Molecular test was performed for confirmation of the species. DNA was extracted from the EDTA blood sample using Qiamp DNA blood Mini kit (M/S Qiagen, Germany) according to the manufacturer's instructions. PCR was carried out in $50 \mu \mathrm{l}$ reaction volumes containing 10X reaction buffer with $\mathrm{KCl}, 25 \mathrm{mM}$ $\mathrm{MgCl}_{2}, 2 \mathrm{mM}$ dNTPs, 3 units of Taq DNA polymerase, $2 \mu \mathrm{M}$ of each primer (Njiru et al. 2005), nuclease free water and $2 \mu \mathrm{l}$ of template DNA. PCR was programmed to perform a denaturation step at $95^{\circ} \mathrm{C}$ for $10 \mathrm{mins}$ followed by 35 cycles consisting of 30 secs at $94^{\circ} \mathrm{C}, 30$ secs at $55^{\circ} \mathrm{C}$, and 30 secs at $72^{\circ} \mathrm{C}$. The last extension step was 10 mins at $72^{\circ} \mathrm{C}$. The PCR product was run in $2 \%$ agarose gel with ethidium bromide-stain using an electrophoresis system (M/S BIO-RAD, USA) along with one positive ( $1 \mu \mathrm{g}$ of DNA) and one negative control (Image 2). After getting the desired band at $480 \mathrm{bp}$, the PCR product was sequenced and the data was compared in National Centre for Biotechnology Information (NCBI) database. The sequenced data matched with $T$. evansi with $93.6 \%$ identity and $97.0 \%$ query cover. The consensus sequence (generated in BIOEDIT software) was submitted in genbank (NCBI) and the assigned accession number was MZ321577.

Analysis results depicted in Table 1 revealed decrease in certain haemato-biochemical values like haemoglobin (6.0 g\%), total leukocyte count $\left(5.010^{3} / \mathrm{mm}^{3}\right)$ neutrophil $(56 \%)$, platelets count $\left(180 \times 10^{3} / \mu \mathrm{l}\right)$ and glucose $(25.7$ $\mathrm{mg} / \mathrm{dl})$. Increased values in both haematological and biochemical parameters included lymphocyte (41\%), AST $(830.4 \mathrm{lU} / \mathrm{l})$, total protein $(7.63 \mathrm{~g} / \mathrm{dl})$, urea $(178.2$ 


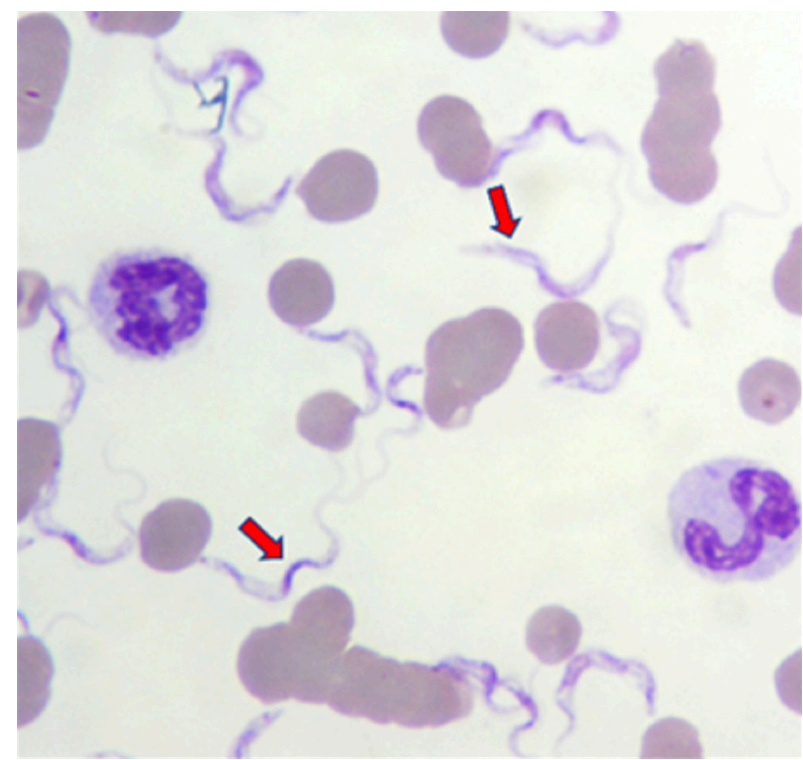

Image 1. Giemsa stained blood smear showing Trypanosoma evansi marked in red arrow (X1000).

$\mathrm{mg} / \mathrm{dl})$, creatinine $(4.44 \mathrm{mg} / \mathrm{dl})$, cholesterol $272.7 \mathrm{mg} /$ $\mathrm{dl})$, triglyceride $(418.8 \mathrm{mg} / \mathrm{dl})$, calcium $(11.1 \mathrm{mg} / \mathrm{dl})$, phosphorous (11.4 mg/dl), magnesium ( $2.7 \mathrm{mg} / \mathrm{dl})$, and total billirubin $(0.80 \mathrm{mg} / \mathrm{dl})$

Quinapyramine sulphate and chloride @ 4.0mg/ kg b wt (Injection Triquin of M/S Vetoquinol India Animal Health Pvt Ltd., Thane) was administered subcutaneously. As supportive therapy, the Indian Wolf was administered with paracetamol inj (Injection Fevastin of M/S Tablets India Limited, Chennai) @ $2.0 \mathrm{ml}$ intramuscular and electrolytes with 20\% dextrose infusion @ 300 ml (Rintose of M/S Vetoquinol India Animal Health Pvt Ltd.). The Indian Wolf started responding to treatment from the very next day itself. Body temperature dropped to $101.4^{\circ} \mathrm{F}$ with signs of improvement in the activity and appetite.

\section{DISCUSSION}

NZKP had the earlier records of trypanosomosis among white Tigers Panthera tigris, Bengal Tigers Panthera tigris tigris, and Jungle Cat Felis chaus (Parija \& Bhattacharya 2001; Sahoo et al. 2009). Hence, the NKZP is following a chemoprohylaxis protocol against trypanosomosis for all large felids $(\mathrm{N}=46)$ and calculated doses of quinapyramine salts (Injection Triquin of M/S Vetoquinol India Animal Health Pvt Ltd, Maharashtra) are being administered subcutaneously at every four month intervals. But the canids were not included in this

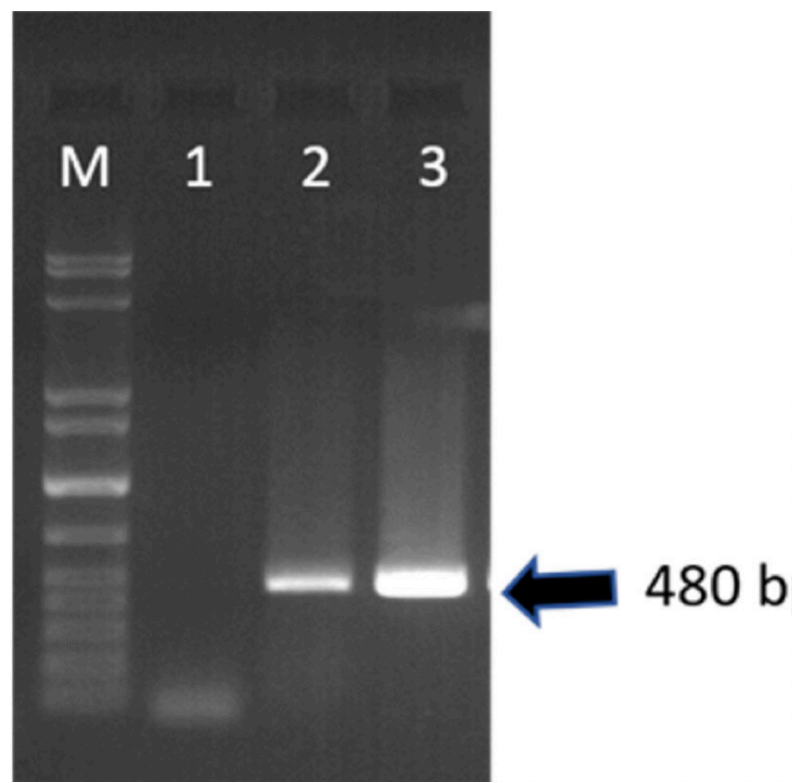

Image 2. Gel electrophoresis of PCR products (480bp). Lane M: 100 bp marker, lane 1: Negative Control, Lane 2: sample of interest, Lane 3: Positive Control.

chemoprophylaxis protocol, as there was no incidence of the said disease amongst canids at NKZP.

It is quite challenging to ascertain the species of Trypanosoma spp. from the blood smear. PCR is the ultimate diagnostic protocol to reveal the fact. PCR targeting internal transcribed spacer (ITS1) region is highly sensitive and reliable for the diagnosis of pathogenic Trypanosoma spp. such as T. evansi, T. brucei brucei, T. b. rhodesiense, $T$. b. gambiense, $T$. congolense, $T$. savannah, $T$. congolense kilifi, $T$. congolense forest, $T$. simiae, T. simiae tsavo, T. godfreyi, and T. vivax (Njiru et al. 2005). Successful detection of Trypanosoma spp. has been reported using ITS1 CF and BR PCR primers in cattle, tsetse fly, sand fly, dogs, equids, monkeys, and camels (Thumbi et al. 2008; Alanazi et al. 2018; Gaithuma et al. 2019; Medkour et al. 2020). The current study unveiled incidence of T. evansi in a captive Indian Wolf at NKZP.

Wild animals often exhibit moderate levels of trypano-tolerance with their innate ability to co-exist with trypanosomes without showing overt disease (Sudan et al. 2017). The disease flares up when the animal gets exposed to physiological and somatic stress following concurrent infection, capture, translocation and captivity that often compromises their innate resistance (Fowler 1986; Singh et al. 2003).

The clinical signs in the present case were high rise of temperature $\left(103.2^{\circ} \mathrm{F}\right)$, pale mucous membrane, bilateral lacrimation, and generalised debility. These observations were in agreement with the findings of Rani 
Table 1. Pre- and post-treatment haemato-biochemical values of an Indian Wolf with Trypanosoma evansi infection.

\begin{tabular}{|c|c|c|c|}
\hline \multirow[b]{2}{*}{ Parameter } & \multicolumn{2}{|c|}{ Days of blood collection } & \multirow[b]{2}{*}{ Reference range } \\
\hline & $\begin{array}{c}24 . i x .2019 \\
\text { (Pre-treatment) }\end{array}$ & $\begin{array}{c}\text { 18.x.2019 } \\
\text { (Post-treatment) }\end{array}$ & \\
\hline \multicolumn{4}{|l|}{ Hematology } \\
\hline Haemoglobin (g \%) & 6.0 & 13.0 & $10.5-15^{a}$ \\
\hline Total leucocyte count $\left(10^{3} / \mathrm{mm}^{3}\right)$ & 5.0 & 5.6 & $5-14.1^{b}$ \\
\hline Neutrophil (\%) & 56.0 & 70.0 & $58-71^{\mathrm{a}}$ \\
\hline Eosinophil (\%) & 3.0 & 3.0 & $0-4^{\mathrm{a}}$ \\
\hline Lymphocyte (\%) & 41.0 & 26.0 & $28-39^{a}$ \\
\hline Monocyte (\%) & - & 1.0 & $0-2^{\mathrm{a}}$ \\
\hline Basophil (\%) & - & 0 & $0^{\mathrm{a}}$ \\
\hline Platelet $\left(\times 10^{3} / \mu \mathrm{l}\right)$ & 180.0 & 226.0 & $211-621^{b}$ \\
\hline \multicolumn{4}{|l|}{ Biochemistry } \\
\hline $\operatorname{ALT}(I U / L)$ & 10.3 & 331.1 & $24-64^{a}$ \\
\hline AST(IU/L) & 830.4 & 159.8 & $23-66^{b}$ \\
\hline ALP(IU/L) & 96.1 & 26.3 & $20-156^{b}$ \\
\hline BUN (mg/dl) & 178.2 & 63.8 & $16-41^{\mathrm{a}}$ \\
\hline Creatinine (mg/dl) & 4.4 & 2.18 & $0.5-1.5^{b}$ \\
\hline Glucose (mg/dl) & 25.7 & 117.2 & $58.2-91^{a}$ \\
\hline Total protein $(\mathrm{g} / \mathrm{dl})$ & 7.63 & 6.4 & $5.07-6.49^{\mathrm{a}}$ \\
\hline Albumin (g/dl) & 1.5 & 2.7 & $2.92-3.53^{\mathrm{a}}$ \\
\hline Globulin (g/dl) & 5.0 & 3.6 & $2.03-3.16^{a}$ \\
\hline Cholesterol (mg/dl) & 272.7 & 178.5 & $138-198^{a}$ \\
\hline Triglyceride(mg/dl) & 418.7 & 39.7 & $20-112^{b}$ \\
\hline Calcium (mg/dl) & 11.1 & 10.9 & $5.58-7.94^{\mathrm{a}}$ \\
\hline Phosphorous (mg/dl) & 11.4 & 2.6 & $4-5.32^{\mathrm{a}}$ \\
\hline Magnesium (mg/dl) & 2.7 & 2.4 & $1.8-2.4^{b}$ \\
\hline Total Billirubin (mg/dl) & 0.8 & 0.8 & $0.10-0.50^{b}$ \\
\hline
\end{tabular}

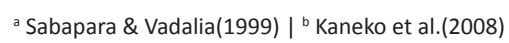

$\&$ Suresh (2007). The fever might be due to the effects of toxic metabolites produced by dying trypanosomes (Tizard et al. 1978).

Anemia was a consistent finding as reported earlier in different hosts including dogs infected with Trypanosomosis (Moreira et al. 1985; Monzon et al. 1991; Silva et al. 1995; Gurtler et al. 2007). The anaemia is attributable to extravascular destruction of RBC which may be through the process of erythrophagocytosis or metabolic product and toxins liberated from the parasites. Blood cellular changes revealed leucopenia along with reduced neutrophil count. Similar findings were recorded by Barr et al. (1991).

Increase in AST, ALT, ALP, urea, creatinine level as compared to reference level corroborated with findings of Barr et al. (1991) who reported a similar pattern of changes in a dog during the acute phase. Marked elevation in the level of total protein values were recorded as compared to reference level. Hyperproteinemia found in this study could be associated with hypergammaglobulinemia due to antigenic stimulation provoked by the parasite, as seen in canines (Aquino et al. 2002). There was a decrease in the albumin and globulin ratio. The fall in albumin levels was secondary to hyperglobulinemia as a compensatory mechanism for maintenance of normal blood viscosity increased by globulin levels (Aquino et al. 2002). Hyperbilirubinemia has been reported in naturally infected dogs as a consequence of an increase in unconjugated bilirubin (Sandoval et al. 1994) and conjugated bilirubin. There was decrease in serum glucose $(25.7 \mathrm{mg} / \mathrm{dl})$ level. Hypoglycemia has been shown to be an important 
clinical laboratory finding in naturally infected animals, and it is inversely proportional to blood trypanosome count.

Diminazine aceturate is a commonly used drug in the treatment of trypanosomosis (Rani \& Suresh 2007). However, a combination of quinapyramine sulphate and quinapyramine chloride $(3: 2 \mathrm{w} / \mathrm{w})$ at dose rate $4.0 \mathrm{mg} / \mathrm{kg} \mathrm{b}$ wt is also effective in achieving complete recovery (Singh et al 1993). Shukla (2002) did not get a complete cure with diminazine@ 0.8g/ 100 kg b. wt in case of an Indian Wolf, rather, quinapyramine sulphate @ 5.0mg/ kg b wt resulted in complete recovery. In a similar line, combination of quinapyramine sulphate and quinapyramine chloride @ $4.0 \mathrm{mg} / \mathrm{kg}$ b wt administered subcutaneously as a single dose showed uneventful recovery in the present case.

The incidence of trypanosomosis in an Indian Wolf became an eye opener for the zoo to extend the chemoprophylaxis to other hosts. As per the recommendation, the susceptible species, viz., Indian Wolf, Jackal, Dhole, and hyenids of NKZP are being included in the preventive protocol against trypanosomosis now.

\section{CONCLUSION}

Molecular diagnosis of Trypanosoma evansi infection in an Indian Wolf followed by successful treatment with a single injection of quinapyramine sulphate and quinapyramine chloride @ $4.0 \mathrm{mg} / \mathrm{kg}$ b wt subcutaneously was recorded at Nandankanan Zoological Park.

\section{REFERENCES}

Alanazi, A.D., R. Puschendorf, B. Salim, M.S. Alyousif, I.O. Alanazi \& H.R. Al-shehri (2018). Molecular detection of equine trypanosomiasis in the Riyadh Province of Saudi Arabia. Journal of Veterinary Diagnostic Investigation 30(6): 942-945. https://doi.org/ 10.1177/1040638718798688

Aquino, L.P.C.T., R.Z. Machado, A.C. Alessi, A.E. Santana, M.B. Castro \& L.C. Marques (2002). Hematological, biochemical and anatomopathological aspects of experimental infection with Trypanosoma evansi in dogs. Arquivo Brasileiro de Medicina Veterinária e Zootecnia 54: 8-18. https://doi.org/10.1590/S0102 09352002000100002

Aulakh, G.S., L.D. Singla \& J. Singh (2005). Bovine trypanosomosis due to Trypanosoma evansi: Clinical, haematobiochemical and therapeutic studies, pp 137-144. In: Sobti, R.C. \& V.L. Sharma (Eds.). New Horizons in Animal Sciences. Vishal Publishing and Co., Jalandhar.

Barr, S.C., K.A. Gossett \& T.R. Klei (1991). Clinical, clinicopathologic, and parasitologic observation of trypanosomiasis in dog infected with North American Trypanosoma cruzi isolates. American Journal of Veterinary Research 52: 954-960

Chaudhuri, S., B. Changkija \& J.P. Varshney (2009). Concurrent infection of Trypanosoma evansi and Dirofilaria immitis in a nondescript bitch. Journal of Veterinary Parasitology 23: 167-169.

Desquenes, M., Z. Bengaly, L. Millogo, Y. Meme \& H. Sakande (2001). The analysis of the cross-reactions occurring in antibody-ELISA for detection of trypanosomes can improve identification of the species involved. Annals of Tropical Medicine and Parasitology 95(2): 141155. https://doi.org/10.1080/00034980120050251

Eloy, L.J. \& S.B. Lucheis (2009). Canine trypanosomiasis: Etiology of infection and implications for public health. Journal of Venomous Animals and Toxins including Tropical Diseases 15(4): 589-611. https://doi.org/10.1590/S1678-91992009000400002

Fowler, M.E. (1986). Zoo and Wild Animal Medicine, $2^{\text {nd }}$ edition. W.B. Saunders company.

Gaithuma, A.K., J. Yamagishi, A. Martinelli, K. Hayashida, N. Kawai \& M. Marsela (2019). A single test approach for accurate and sensitive detection and taxonomic characterization of trypanosomes by comprehensive analysis of internal transcribed spacer 1 amplicons PLoS Neglected Tropical Diseases 13(2): e0006842. https://doi. org/10.1371/journal.pntd.0006842

Gupta, M.P., H. Kumar \& L.D. Singla (2009). Trypanosomosis concurrent to tuberculosis in black bucks. The Indian Veterinary Journal 86: 727-728.

Gurtler, R.E., M.C. Cecere, M. A. Lauricella, M.V. Cardinal, U. Kitron \& J.E. Cohen (2007). Domestic dogs and cats as source of Trypanosoma cruzi infection in rural northwestern Argentina. Parasitology 134: 69-82. https://doi.org/10.1017/S0031182006001259

Kaneko, J.J., J. Harvey \& M.L. Bruss (2008). Clinical Biochemistry of Domestic Animals - 6th Edition. Academic Press, San Diego, pp. 873904. https://doi.org/10.1016/B978-0-12-370491-7.00033-7

Kumar, H., M.P. Gupta, P.K. Sidhu, V. Mahajan, M.S. Bal, K. Kaur, Ashuma, S. Verma \& L.D. Singla (2012). An outbreak of acute Trypanosoma evansi infection in crossbred cattle in Punjab, India. Journal of Applied Animal Research 40(03): 256-259. https://doi.or g/10.1080/09712119.2012.667651

Medkour, H., M. Varloud, B. Davoust \& O. Mediannikov (2020). New molecular approach for the detection of kinetoplastida parasites of medical and veterinary interest. Microorganisms 8: 356. https://doi. org/10.3390/microorganisms8030356

Monzon, C.M., V.I. Villavicencio \& J.P. Roux (1991). Estudioshematológicosencobaios y equinosinfectados Con el Trypanosoma evansi. Veterinary Argent 8: 668-676.

Moreira, R.D. \& R.Z. Machado (1985). Identificaçãoeisolamento do Trypanosoma equinumem um cãodomunicípio De Camapuã-MS, pp. 66. In: Encontro de pesquisasveterinárias, jaboticabal. resumo... jaboticabal: UNESP/Faculdade de Ciências Agrárias.

Njiru, Z.K., C.C. Constantine, S. Guya, J. Crowther, J.M. Kiragu, R.C.A. Thompson \& A.M.R. Dávila (2005). The use of ITS1 rDNA PCR in detecting pathogenic African trypanosomes. Parasitology Research 95: 186-192.

Parashar, B.S., V. Singh, S. Prakash \& V. Kumar (2006). Prevalence of blood sucking flies, vector of trypanosomiasis in the Nandankanan Zoological Park, Bhubaneswar (Orissa) and their control by integrated pest management. In: Indian Zoo Year Book 4: 112-125.

Parashar, R., L.D. Singla, K. Batra, R. Kumar, N. Kashyap, P. Kaur \& M.S. Bal (2018). Unraveling cryptic epizootiology of equid trypanosomosis in Punjab state of India by parasitological and seromolecular techniques. Acta Tropica 185: 18-26.

Parija, S.C. \& S. Bhattacharya (2001). Tragedy of tigers: Lessons to learn from Nandankanan episode. Indian Journal of Medical Microbiology 19: 116-118.

Rani, N.L. \& K. Suresh (2007). Canine trypanosomiasis. Indian Veterinary Journal 84: 186-187.

Sabapara, R.H. \& D.M. Vadalia (1999). Haematology and serum chemistry of Indian Wolf (Canis lupus pallipes). Zoos' Print Journal 14: 92-93. https://doi.org/10.11609/JoTT.ZPJ.14.8.92-3

Sahoo, N., P.K. Roy, R.K. Samantaray \& A. Das (2009). Treatment of trypanosomiasis in a Jungle Cat. Indian Veterinary Journal 86(8): 
844-845.

Sandoval, G.L., N.B. Coppo \& M.S. Negrette (1994) Alteraçõesbioquímicas e histopatológicas de um cãoeratosinfectados com Trypanosoma evansi. Hora Vet 81: 53-55.

Sengupta, M.R. (1974). A preliminary report on diseases and parasites of zoo animals, birds and reptiles. Indian Journal of Animal Health 13: $15-24$.

Silva, R.A.M.S., A.T.M. Barros \& H.M. Herrera (1995). Trypanosomosis outbreaks due to Trypanosoma evansi in the Pantanal, Brazil. A preliminary approachon risk factors. Revue d'élevage et de médecinevétérinaire des pays tropicaux 48: 315-319.

Singh, R., L.D. Singla \& P.S. Dhaliwal (2003). Dexamethasone flared up trypanosomosis in a dog. Indian Veterinary Medical Journal 27: 93-94

Shukla, U. (2002). Trypanosomiasis in wolf (Canis lupus)- a case study for Lucknow Zoo. Zoos' Print Journal 17: 862. https://doi. org/10.11609/JoTT.ZPJ.17.8.862
Sudan, V., A.K. Verma \& A.K. Jaiswal (2017). Trypanosomiasis of wild animals with emphasis on Indian scenario. Veterinary Parasitology Regional Studies and Reports 10: 25-28. https://doi.org/10.1016/j. vprsr.2017.07.003

Singh, B., I.S. Kalra, M.P. Gupta \& D.C. Nauriyal (1993). Trypanosoma evansi in dogs: seasonal prevalence and chemotherapy. Veterinary Parasitology 50: 137-141.

Thumbi, S.M., F.A. McOdimba \& R.O. Mosi (2008). Comparative evaluation of three PCR base diagnostic assays for the detection of pathogenic trypanosomes in cattle blood. Parasites Vectors 1: 46 https://doi.org/10.1186/1756-3305-1-46

Tizard, I.R., K.H. Nielsen, J.R. Seed \& J.E. Hall (1978). Biologically active products from African trypanosomes. Microbiological Reviews 42: 661-681. https://doi.org/10.1128/mr.42.4.664-681.1978

Ziauddin, K.S., K. Muralidharan \& S.J. Seshadri (1992). Trypanosomiasis in a wolf at Mysore Aoo- a case report. Indian Journal of Wildlife Health Management 1: 47. 
Dr. John Noyes, Natural History Museum, London, UK

Dr. Albert G. Orr, Griffith University, Nathan, Australia

Dr. Sameer Padhye, Katholieke Universiteit Leuven, Belgium

Dr. Nancy van der Poorten, Toronto, Canada

Dr. Kareen Schnabel, NIWA, Wellington, New Zealand

Dr. R.M. Sharma, (Retd.) Scientist, Zoological Survey of India, Pune, India

Dr. Manju Siliwal, WILD, Coimbatore, Tamil Nadu, India

Dr. G.P. Sinha, Botanical Survey of India, Allahabad, India

Dr. K.A. Subramanian, Zoological Survey of India, New Alipore, Kolkata, India

Dr. P.M. Sureshan, Zoological Survey of India, Kozhikode, Kerala, India

Dr. R. Varatharajan, Manipur University, Imphal, Manipur, India

Dr. Eduard Vives, Museu de Ciències Naturals de Barcelona, Terrassa, Spain

Dr. James Young, Hong Kong Lepidopterists' Society, Hong Kong

Dr. R. Sundararaj, Institute of Wood Science \& Technology, Bengaluru, India

Dr. M. Nithyanandan, Environmental Department, La Ala Al Kuwait Real Estate. Co. K.S.C.,

Kuwait

Dr. Himender Bharti, Punjabi University, Punjab, India

Mr. Purnendu Roy, London, UK

Dr. Saito Motoki, The Butterfly Society of Japan, Tokyo, Japan

Dr. Sanjay Sondhi, TITLI TRUST, Kalpavriksh, Dehradun, India

Dr. Nguyen Thi Phuong Lien, Vietnam Academy of Science and Technology, Hanoi, Vietnam

Dr. Nitin Kulkarni, Tropical Research Institute, Jabalpur, India

Dr. Robin Wen Jiang Ngiam, National Parks Board, Singapore

Dr. Lional Monod, Natural History Museum of Geneva, Genève, Switzerland.

Dr. Asheesh Shivam, Nehru Gram Bharti University, Allahabad, India

Dr. Rosana Moreira da Rocha, Universidade Federal do Paraná, Curitiba, Brasi

Dr. Kurt R. Arnold, North Dakota State University, Saxony, Germany

Dr. James M. Carpenter, American Museum of Natural History, New York, USA

Dr. David M. Claborn, Missouri State University, Springfield, USA

Dr. Kareen Schnabel, Marine Biologist, Wellington, New Zealand

Dr. Amazonas Chagas Júnior, Universidade Federal de Mato Grosso, Cuiabá, Brasil

Mr. Monsoon Jyoti Gogoi, Assam University, Silchar, Assam, India

Dr. Heo Chong Chin, Universiti Teknologi MARA (UiTM), Selangor, Malaysia

Dr. R.J. Shiel, University of Adelaide, SA 5005, Australia

Dr. Siddharth Kulkarni, The George Washington University, Washington, USA

Dr. Priyadarsanan Dharma Rajan, ATREE, Bengaluru, India

Dr. Phil Alderslade, CSIRO Marine And Atmospheric Research, Hobart, Australia

Dr. John E.N. Veron, Coral Reef Research, Townsville, Australia

Dr. Daniel Whitmore, State Museum of Natural History Stuttgart, Rosenstein, Germany.

Dr. Yu-Feng Hsu, National Taiwan Normal University, Taipei City, Taiwan

Dr. Keith V. Wolfe, Antioch, California, USA

Dr. Siddharth Kulkarni, The Hormiga Lab, The George Washington University, Washington,

D.C., USA

Dr. Tomas Ditrich, Faculty of Education, University of South Bohemia in Ceske

Budejovice, Czech Republic

Dr. Mihaly Foldvari, Natural History Museum, University of Oslo, Norway

Dr. V.P. Uniyal, Wildlife Institute of India, Dehradun, Uttarakhand 248001, India

Dr. John T.D. Caleb, Zoological Survey of India, Kolkata, West Bengal, India

Dr. Priyadarsanan Dharma Rajan, Ashoka Trust for Research in Ecology and the Environment

(ATREE), Royal Enclave, Bangalore, Karnataka, India

\section{Fishes}

Dr. Neelesh Dahanukar, IISER, Pune, Maharashtra, India

Dr. Topiltzin Contreras MacBeath, Universidad Autónoma del estado de Morelos, México

Dr. Heok Hee Ng, National University of Singapore, Science Drive, Singapore

Dr. Rajeev Raghavan, St. Albert's College, Kochi, Kerala, India

Dr. Robert D. Sluka, Chiltern Gateway Project, A Rocha UK, Southall, Middlesex, UK

Dr. E. Vivekanandan, Central Marine Fisheries Research Institute, Chennai, India

Dr. Davor Zanella, University of Zagreb, Zagreb, Croatia

Dr. A. Biju Kumar, University of Kerala, Thiruvananthapuram, Kerala, India

Dr. Akhilesh K.V., ICAR-Central Marine Fisheries Research Institute, Mumbai Research

Centre, Mumbai, Maharashtra, India

Dr. J.A. Johnson, Wildlife Institute of India, Dehradun, Uttarakhand, India

Amphibians

Dr. Sushil K. Dutta, Indian Institute of Science, Bengaluru, Karnataka, India

Dr. Annemarie Ohler, Muséum national d'Histoire naturelle, Paris, France

\section{Reptiles}

Dr. Gernot Vogel, Heidelberg, Germany

Dr. Raju Vyas, Vadodara, Gujarat, India

Dr. Pritpal S. Soorae, Environment Agency, Abu Dubai, UAE.

Prof. Dr. Wayne J. Fuller, Near East University, Mersin, Turkey

Prof. Chandrashekher U. Rivonker, Goa University, Taleigao Plateau, Goa. India

Dr. S.R. Ganesh, Chennai Snake Park, Chennai, Tamil Nadu, India

Dr. Himansu Sekhar Das, Terrestrial \& Marine Biodiversity, Abu Dhabi, UAE
Birds

Dr. Hem Sagar Baral, Charles Sturt University, NSW Australia

Dr. Chris Bowden, Royal Society for the Protection of Birds, Sandy, UK

Dr. Priya Davidar, Pondicherry University, Kalapet, Puducherry, India

Dr. J.W. Duckworth, IUCN SSC, Bath, UK

Dr. Rajah Jayapal, SACON, Coimbatore, Tamil Nadu, India

Dr. Rajiv S. Kalsi, M.L.N. College, Yamuna Nagar, Haryana, India

Dr. V. Santharam, Rishi Valley Education Centre, Chittoor Dt., Andhra Pradesh, India

Dr. S. Balachandran, Bombay Natural History Society, Mumbai, India

Mr. J. Praveen, Bengaluru, India

Dr. C. Srinivasulu, Osmania University, Hyderabad, India

Dr. K.S. Gopi Sundar, International Crane Foundation, Baraboo, USA

Dr. Gombobaatar Sundev, Professor of Ornithology, Ulaanbaatar, Mongolia

Prof. Reuven Yosef, International Birding \& Research Centre, Eilat, Israel

Dr. Taej Mundkur, Wetlands International, Wageningen, The Netherlands

Dr. Carol Inskipp, Bishop Auckland Co., Durham, UK

Dr. Tim Inskipp, Bishop Auckland Co, Durham, UK

Dr. V. Gokula, National College, Tiruchirappalli, Tamil Nadu, India

Dr. Arkady Lelej, Russian Academy of Sciences, Vladivostok, Russia

Dr. Simon Dowell, Science Director, Chester Zoo, UK

Dr. Mário Gabriel Santiago dos Santos, Universidade de Trás-os-Montes e Alto Douro,

Quinta de Prados, Vila Real, Portugal

Dr. Grant Connette, Smithsonian Institution, Royal, VA, USA

Dr. M. Zafar-ul Islam, Prince Saud Al Faisal Wildlife Research Center, Taif, Saudi Arabia

Mammals

Dr. Giovanni Amori, CNR - Institute of Ecosystem Studies, Rome, Italy

Dr. Anwaruddin Chowdhury, Guwahati, India

Dr. David Mallon, Zoological Society of London, UK

Dr. Shomita Mukherjee, SACON, Coimbatore, Tamil Nadu, India

Dr. Angie Appel, Wild Cat Network, Germany

Dr. P.O. Nameer, Kerala Agricultural University, Thrissur, Kerala, India

Dr. Ian Redmond, UNEP Convention on Migratory Species, Lansdown, UK

Dr. Heidi S. Riddle, Riddle's Elephant and Wildlife Sanctuary, Arkansas, USA

Dr. Karin Schwartz, George Mason University, Fairfax, Virginia.

Dr. Lala A.K. Singh, Bhubaneswar, Orissa, India

Dr. Mewa Singh, Mysore University, Mysore, India

Dr. Paul Racey, University of Exeter, Devon, UK

Dr. Honnavalli N. Kumara, SACON, Anaikatty P.O., Coimbatore, Tamil Nadu, India

Dr. Nishith Dharaiya, HNG University, Patan, Gujarat, India

Dr. Spartaco Gippoliti, Socio Onorario Società Italiana per la Storia della Fauna "Giuseppe

Altobello", Rome, Italy

Dr. Justus Joshua, Green Future Foundation, Tiruchirapalli, Tamil Nadu, India

Dr. H. Raghuram, The American College, Madurai, Tamil Nadu, India

Dr. Paul Bates, Harison Institute, Kent, UK

Dr. Jim Sanderson, Small Wild Cat Conservation Foundation, Hartford, USA

Dr. Dan Challender, University of Kent, Canterbury, UK

Dr. David Mallon, Manchester Metropolitan University, Derbyshire, UK

Dr. Brian L. Cypher, California State University-Stanislaus, Bakersfield, CA

Dr. S.S. Talmale, Zoological Survey of India, Pune, Maharashtra, India

Prof. Karan Bahadur Shah, Budhanilakantha Municipality, Kathmandu, Nepal

Dr. Susan Cheyne, Borneo Nature Foundation International, Palangkaraja, Indonesia

Dr. Hemanta Kafley, Wildlife Sciences, Tarleton State University, Texas, USA

\section{Other Disciplines}

Dr. Aniruddha Belsare, Columbia MO 65203, USA (Veterinary)

Dr. Mandar S. Paingankar, University of Pune, Pune, Maharashtra, India (Molecular)

Dr. Jack Tordoff, Critical Ecosystem Partnership Fund, Arlington, USA (Communities)

Dr. Ulrike Streicher, University of Oregon, Eugene, USA (Veterinary)

Dr. Hari Balasubramanian, EcoAdvisors, Nova Scotia, Canada (Communities)

Dr. Rayanna Hellem Santos Bezerra, Universidade Federal de Sergipe, São Cristóvão, Brazil

Dr. Jamie R. Wood, Landcare Research, Canterbury, New Zealand

Dr. Wendy Collinson-Jonker, Endangered Wildlife Trust, Gauteng, South Africa

Dr. Rajeshkumar G. Jani, Anand Agricultural University, Anand, Gujarat, India

Dr. O.N. Tiwari, Senior Scientist, ICAR-Indian Agricultural Research Institute (IARI), New

Delhi, India

Dr. L.D. Singla, Guru Angad Dev Veterinary and Animal Sciences University, Ludhiana, India

Dr. Rupika S. Rajakaruna, University of Peradeniya, Peradeniya, Sri Lanka

Dr. Bahar Baviskar, Wild-CER, Nagpur, Maharashtra 440013, India

Reviewers 2018-2020

Due to pausity of space, the list of reviewers for $2018-2020$ is available online.

The opinions expressed by the authors do not reflect the views of the Journal of Threatened Taxa, Wildlife Information Liaison Development Society, Zoo Outreach Organization, or any of the partners. The journal, the publisher, the host, and the partners are not responsible for the accuracy of the political boundaries shown in the maps by the authors.

Journal of Threatened Taxa is indexed/abstracted in Bibliography of Systematic Mycology, Biological Abstracts, BIOSIS Previews, CAB Abstracts, EBSCO, Google Scholar, Index Copernicus, Index Fungorum, JournalSeek, National Academy of Agricultural Sciences, NewJour, OCLC WorldCat, SCOPUS, Stanford University Libraries, Virtual Library of Biology, Zoological Records.

NAAS rating (India) 5.64
Print copies of the Journal are available at cost. Write to:

The Managing Editor, JoTT,

c/o Wildlife Information Liaison Development Society,

No. 12, Thiruvannamalai Nagar, Saravanampatti - Kalapatti Road,

Saravanampatti, Coimbatore, Tamil Nadu 641035, India

ravi@threatenedtaxa.org 


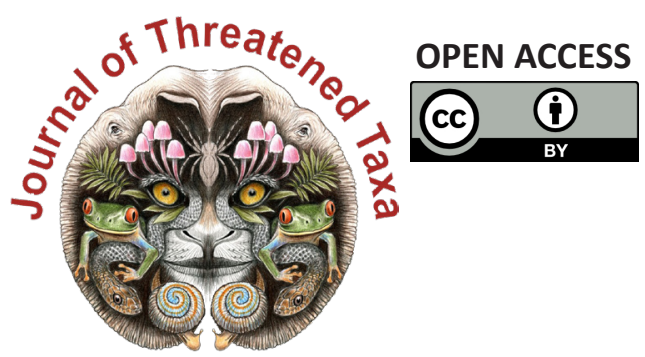

www.threatenedtaxa.org

The Journal of Threatened Taxa (JoTT) is dedicated to building evidence for conservation globally by publishing peer-reviewed articles online every month at a reasonably rapid rate at www.threatenedtaxa.org. All articles published in JoTT are registered under Creative Commons Attribution 4.0 International License unless otherwise mentioned. JoTT allows allows unrestricted use, reproduction, and distribution of articles in any medium by providing adequate credit to the author(s) and the source of publication.

\section{ISSN $0974-7907$ (Online) | ISSN $0974-7893$ (Print)}

\section{January 2022 | Vol. 14 | No. 1 | Pages: 20311-20538 \\ Date of Publication: 26 January 2022 (Online \& Print) DOI: 10.11609/jott.2022.14.1.20311-20538}

Articles

Estimating the completeness of orchid checklists and atlases: a case study from southern Italy

- Antonio Croce, Pp. 20311-20322

A floristic survey across three coniferous forests of Kashmir Himalaya, India - a checklist

- Ashaq Ahmad Dar, Akhtar Hussain Malik \& Narayanaswamy Parthasarathy, Pp. 20323-20345

Associations of butterflies across different forest types in Uttarakhand, western Himalaya, India: implications for conservation planning

- Arun Pratap Singh, Pp. 20346-20370

Comparison of bird diversity in protected and non-protected wetlands of western lowland of Nepal

- Jagan Nath Adhikari, Janak Raj Khatiwada, Dipendra Adhikari, Suman Sapkota, Bishnu Prasad Bhattarai, Deepak Rijal \& Lila Nath Sharma, Pp. 20371-20386

Local hunting practices and perceptions regarding the distribution and ecological role of the Large Flying Fox (Chiroptera: Pteropodidae: Pteropus vampyrus) in western Sarawak, Malaysian Borneo

- Jayasilan Mohd-Azlan, Joon Yee Yong, Nabila Norshuhadah Mohd Hazzrol, Philovenny Pengiran, Arianti Atong \& Sheema Abdul Aziz, Pp. 20387-20399

\section{Communications}

Macrolichens of Mathikettan Shola National Park, Western Ghats: a preliminary investigation with some new records

- Aswathi Anilkumar, Stephen Sequeira, Arun Christy \& S.M. Arsha, Pp. 20400-20405

New distribution record of globally threatened Ocean Turf Grass Halophila beccarii Ascherson, 1871 from the North Andaman Islands highlights the importance of seagrass exploratory surveys

- Swapnali Gole, Prasad Gaidhani, Srabani Bose, Anant Pande, Jeyaraj Antony Johnson \& Kuppusamy Sivakumar, Pp. 20406-20412

An inventory of new orchid (Orchidaceae) records from Kozhikode, Kerala, India - M. Sulaiman, C. Murugan \& M.U. Sharief, Pp. 20413-20425

Abundance and spatial distribution analyses of Stemonoporus moonii Thwaites (Dipterocarpaceae) - a critically endangered species endemic to Sri Lanka - K.A.M.R.P. Atapattu, H.D.D.C.K. Perera, H.S. Kathriarachchi \& A.R. Gunawardena, Pp. 20426-20432

Plant diversity of Point Calimere Wildlife Sanctuary and fodder species grazed by the Blackbuck Antilope cervicapra L.

- Ashutosh Kumar Upadhyay, A. Andrew Emmanuel, Ansa Sarah Varghese \&

D. Narasimhan, Pp. 20433-20443

Raptors observed (1983-2016) in National Chambal Gharial Sanctuary: semi-arid biogeographic region suggestions for parametric studies on ecological continuity in Khathiar-Gir Ecoregion, India

- L.A.K. Singh, R.K. Sharma \& Udayan Rao Pawar, Pp. 20444-20460

Nesting success of Sharpe's Longclaw (Macronyx sharpei Jackson, 1904) around the grasslands of lake Ol'bolossat Nyandarua, Kenya

- Hamisi Ann Risper, Charles M. Warui \& Peter Njoroge, Pp. 20461-20468

Population, distribution and diet composition of Smooth-coated Otter Lutrogale perspicillata Geoffroy, 1826 in Hosur and Dharmapuri Forest Divisions, India - Nagarajan Baskaran, Raman Sivaraj Sundarraj \& Raveendranathanpillai Sanil, Pp. 20469-20477

Utilization of home garden crops by primates and current status of human-primate interface at Galigamuwa Divisional Secretariat Division in Kegalle District, Sri Lanka

- Charmalie Anuradhie Dona Nahallage, Dahanakge Ayesha Madushani Dasanayake, Dilan Thisaru Hewamanna \& Dissanayakalage Tharaka Harshani Ananda, Pp. 2047820487
Revival of Eastern Swamp Deer Rucervus duvaucelii ranjitsinhi (Groves, 1982) in Manas National Park of Assam, India

- Nazrul Islam, Aftab Ahmed, Rathin Barman, Sanatan Deka, Bhaskar Choudhury, Prasanta Kumar Saikia \& Jyotishman Deka, Pp. 20488-20493

Trypanosoma evansi infection in a captive Indian Wolf Canis lupus pallipes - molecular diagnosis and therapy

- Manojita Dash, Sarat Kumar Sahu, Santosh Kumar Gupta, Niranjana Sahoo \& Debarat Mohapatra, Pp. 20494-20499

View Point

COVID-19 and civil unrest undoing steady gains in karst conservation and herpetological research in Myanmar, and an impediment to progress - Evan S.H. Quah, Lee L. Grismer, Perry L. Wood, Jr., Aung Lin \& Myint Kyaw Thura, Pp. 20500-20502

\section{Short Communications}

Morphological characterization and mt DNA barcode of a tiger moth species, Asota ficus (Fabricius, 1775) (Lepidoptera: Noctuoidea: Erebidae: Aganainae) from India - Aparna Sureshchandra Kalawate, K.P. Dinesh \& A. Shabnam, Pp. 20503-20510

Distribution of Smooth-coated Otters Lutrogale perspicillata (Mammalia: Carnivora: Mustelidae): in Ratnagiri, Maharashtra, India

- Swanand Patil \& Kranti Yardi, Pp. 20511-20516

Wildlife at the crossroads: wild animal road kills due to vehicular collision on a mountainous highway in northwestern Himalayan region

- Muzaffar A. Kichloo, Asha Sohil \& Neeraj Sharma, Pp. 20517-20522

Notes

Robiquetia gracilis (Lindl.) Garay-a new record to the flora of Anamalai Hills, Tami Nadu, India

- B. Subbaiyan, V. Ganesan, P.R. Nimal Kumar \& S. Thangaraj Panneerselvam, Pp. 20523-20525

Ipomoea laxiflora H.J. Chowdhery \& Debta (Convolvulaceae): new records for the Western Ghats and semiarid regions

- Sachin M. Patil, Ajit M. Vasava, Vinay M. Raole \& Kishore S. Rajput, Pp. 20526-20529

Counting the cost: high demand puts Bunium persicum (Boiss.) B.Fedtsch. in jeopardy

- Monika Sharma, Manisha Mathela, Rupali Sharma, Himanshu Bargali, Gurinderjit S Goraya \& Amit Kumar, Pp. 20530-20533

First record of Parasitic Jaeger Stercorarius parasiticus (Aves: Charadriiformes: Stercorariidae) from inland freshwater Inle Lake, Myanmar

- Sai Sein Lin Oo, Myint Kyaw, L.C.K. Yun, Min Zaw Tun, Yar Zar Lay Naung, Soe Naing Aye \& Swen C. Renner, Pp. 20534-20536

\section{Book Review}

Capparis of India

- V. Sampath Kumar, Pp. 20537-20538
Publisher \& Host
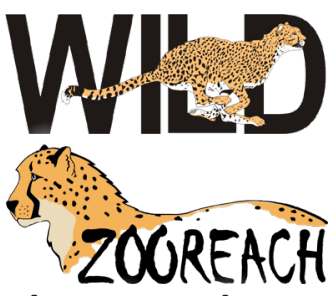

Threatened Taxa 